\title{
Evaluation of Red and Green Colored Bell peppers for the Production of Polyclonal IgM and IgG Antibodies in Murine Spleen Cells
}

\author{
Md. Moklesur Rahman Sarker ${ }^{1,2,3}$ \\ ${ }^{1}$ Department of Immunochemistry, Faculty of Pharmaceutical Sciences, Okayama University Tsushima-naka \\ Kita-ku, Okayama 700-8530, Japan \\ ${ }^{2}$ Department of Pharmacy, State University of Bangladesh, 77 Satmasjid Road, Dhanmandi \\ Dhaka 1205, Bangladesh \\ ${ }^{3}$ Health Med Science Research Limited, 3/1 Block F, Lalmatia, Dhaka 1207, Bangladesh
}

(Received: September 25, 2020; Accepted: January 12, 2021; Published (web): January 28, 2021)

\begin{abstract}
Immunostimulants are greatly required for the upregulation of immunity to fight against viral and bacterial infections and cancers. Bell peppers (Capsicum annuum L.), eaten as vegetables, are rich sources of vitamin $\mathrm{C}$ and $\mathrm{E}$, provitamin $\mathrm{A}, \beta$-carotene, and numerous phenolic compounds. Antimicrobial, antioxidant, anti-mutagenic and anti-inflammatory properties of Bell peppers were reported. Our research group for the first time reported the immunomodulatory activities of Bell peppers. In this study, we evaluated the antibody production abilities of two different colored Bell peppers (red and green) in the culture of antibody producing splenic B cells of mice. Antibodies and the number of viable cells were determined by an ELISA and MTT assays, respectively. Red Bell pepper Extract (RBPE) at the doses of $(0.375,0.75,1.5$, and $2.25 \mathrm{mg} / \mathrm{mL})$ significantly augmented the production of polyclonal $\operatorname{IgM}$ and $\operatorname{IgG}$ antibodies in-vitro. The highest amount of $\operatorname{IgM}$ antibody production was observed by the dose of $1.5 \mathrm{mg} / \mathrm{kg}$ which was 3 times higher than that of the untreated cells. Similarly, RBPE also enhanced the production of IgG antibody in the culture of murine splenic B cells. On the contrary, cultural treatment of murine splenic B cells with Green Bell pepper Extract (GBPE) could not stimulate the B cells, and hence, failed to produce neither IgM nor IgG antibody. Thus the current findings suggest that consumption of Red Bell Pepper extract or its vegetables, not green pepper, may be beneficial to strengthen humoral immune responses.
\end{abstract}

Key words: Red Bell pepper (Capsicum annuum L.), Green Bell pepper, Plant extract, Functional foods, Splenocytes, Proliferation, Differentiation, IgM Antibody, IgG antibody, Immunostimulant

\section{Introduction}

Immunity is an important factor for the prevention of microorganisms, hence possible infections, and cancers. Human body has its own defensive capacity to protect it from the infectious pathogens, such as bacteria, viruses, fungus, etc., and to eliminate/destroy cancer cells as soon as they appear thus protects the body against infection and disease (Günther and Seyfert, 2018). It is a complex and integrated system of cells, tissues, and organs that has specialized roles in defending against foreign substances and pathogenic microorganisms, including viruses. Thus, a healthy immune system by its selfsurveillance mechanism prevents all sorts of viral and bacterial infectious (Sarker and Gohda, 2013). Unfortunately, the defensive capacity of the immune system is impaired by many factors and in many conditions, such as stress (Vitlic et al., 2014), aging (Vitlic et al., 2014), chronic insomnia (Besedovsky et al., 2019), lack of exercise or sedentary life-style and poor nutrition (Hickman et al., 2014), obesity (Zlotnikov et al., 2017), in conditions like diabetes

Corresponding author: Md. Moklesur Rahman Sarker; Email: moklesur2002@yahoo.com; dr.moklesur2014@gmail.com Tel.: +8801776758882

DOI: $\underline{\text { https://doi.org/10.3329/bpj.v24i1.51635 }}$ 
(Toniolo et al., 2019), cancer (Goswami et al., 2017), intake of adulterated foods, acquired immunodeficiency syndrome (AIDS) (Paiardini et al., 2008), burn and sepsis (Ren et al., 2020), etc. Immunity is also suppressed greatly in patients receiving chemotherapy and radiotherapy. Intake of antibiotics destroys immune cells and worsen all sorts of microbial infections (Ankomah et al., 2014). In addition, intake of most of the medicines adversely impact on immunity (Kidd et al., 2016). Almost everybody is more or less exposed to one or more of the above factors impairing immunity. Therefore, people are susceptible to infection and the body's immune system cannot prevent the entry of microbes and further defeat causing from infections. Administrations of external immunostimulants, especially dietary materials having therapeutic value due to the presence of bioactive compounds, play a significant role for the up-regulation of the immune system to prevent the entry of microorganisms and further progress of the infections caused by bacteria and viruses as well as for the prevention of cancers.

In recent days, functional foods, nutraceuticals and phytomedicines have attracted the attention of researchers and healthcare givers, specially for therapeutic benefits without or with minimum sideeffects (Chen et al., 2019; Chen et al., 2018; Das et al., 2017; Kamarudin et al., 2017; Karim et al., 2015; Khan et al., 2019; Munira et al., 2020; Nesa et al., 2018). Bell peppers (Capsicum aпnиит L.) are eaten all over the world as fresh, healthy and tasty vegetables are available in red, green, orange, yellow and black colours. Although all types of Bell peppers are good sources of antioxidants, such as vitamin C, provitamin A, vitamin $\mathrm{E}$, and flavonoids (Ghasemnezhad et al., 2011), the nutritional contents and phytoconstituents are also varied among different coloured Bell peppers. Scientific investigations on Bell pepper extracts and its constituents have been reported to exhibit anti-microbial, anti-mutagenic, anti-cancer, and anti-inflammatory (Sancho et al., 2002; Park et al., 2012)) properties. However, effects of Bell peppers in immunity were not studied. We for the first time reported the immunostimulating potential of red Bell pepper extract (RBPE) which potently promoted the productions of both the polyclonal immunoglobulin (Ig) M (Goto et al., 2010) and antigen-specific IgM and IgG antibodies in murine $\mathrm{B}$ cells in vitro and ex vivo (Sarker and Gohda, 2013). So far the immunostimulating activities of other colors of Bell peppers have not yet been reported. We, therefore, aimed to evaluate the effects of red and green coloured Bell pepper extracts to stimulate the production of $\operatorname{IgM}$ and $\operatorname{IgG}$ antibodies as well as the proliferation of antibody producing splenic B cells in vitro.

\section{Materials and methods}

Chemicals and reagents: Roswell Park Memorial Institute (RPMI) 1640 medium was purchased from ICN Biomedicals (Irvine, CA, USA), lipopolysaccharide (LPS) from Escherichia coli 055:B5, 3-(4,5-dimethylthiazol-2-yl)-2,5-diphenylterazolium bromide (MTT), bovine serum albumin (BSA) (Fraction V), Sigma Fast o-phenylenediamine (OPD), and fetal calf serum (FCS) were obtained from Sigma-Aldrich Co. (St. Louis, MO, USA). Horseradish peroxidase (HRP)-conjugated goat antimouse IgM and anti-mouse $\operatorname{IgG}$ were obtained from Kirkegaad \& Perry Laboratories (Gaithersburg, MD, USA).

Freeze-dried powder of red and green coloured Bell peppers: Fleshes of red and green Bell peppers, cultivated in Miyazaki Agricultural Research Institute, were freeze-dried and powdered using a mill equipped with a $0.5 \mathrm{~mm}$ screen (Ultra Centrifugal Mill EM-1, MRK-RETSCH) at Miyazaki Prefecture Foods Research and Development (R\&D) Centre (Miyazaki, Japan). The freeze-dried powder material was kindly donated to our laboratory for experiment purposes in the year 2008.

Preparation of Bell pepper extracts: One gram of Bell pepper powder was mixed with 10 volumes of phosphate buffered saline (PBS) with continuous stirring at $40^{\circ} \mathrm{C}$ by magnetic stirrer for $1.5 \mathrm{~h}$ followed by being centrifuged at $21000 \times g$ for $20 \mathrm{~min}$ and $4^{\circ} \mathrm{C}$. The supernatant was collected by decantation as extract. The resulting precipitate was again mixed with 5 volumes of PBS for another $1.5 \mathrm{~h}$ under 
continuous stirring followed by centrifugation, and the supernatants were collected, as previously mentioned, and combined with the previous supernatants. The $\mathrm{pH}$ of the collected supernatants was measured about 7 , and these were passed through three consecutive membrane filters having pore size of 5.0, 0.45 and $0.22 \mu \mathrm{m}$, and the filtrate was stored at $-80{ }^{\circ} \mathrm{C}$ for until use. The concentration (w/v) of the extract was calculated by subtracting the weight of lyophilized PBS of the same volume from the weight of the lyophilized PBS extract.

Mice: Female BALB/c mice were purchased from Charles River Japan (Yokohama, Japan). The mice were maintained under specific pathogen-free conditions in the animal facility of Okayama University and used between 8 and 12 weeks of age. All experimental procedures concerned with mice were performed according to the guidelines established by the Ministry of Education, Culture, Sports, Science and Technology of Japan, and to the Guidelines for Animal Experiments at Okayama University and were approved by the Animal Research Control Committee of Okayama University, Japan.

Cell culture and re-culture with the treatment of Bell pepper extracts: Cell culture and re-culture for antibody production were performed as described previously (Sarker et al., 2014; Sarker et al., 2012a; Sarker, 2012). Whole splenocytes from BALB/c female mice, depleted of erythrocytes, were prepared by lysis of erythrocytes with ACK lysis buffer ( 0.15 $\mathrm{M} \mathrm{NH}{ }_{4} \mathrm{Cl}, 10 \mathrm{mM} \mathrm{KHCO} 3,0.1 \mathrm{mM} \mathrm{Na}{ }_{2}$ EDTA; pH 7.2). Freshly prepared splenocytes were suspended in basal culture medium (Rosewell Park Memorial Institute/RPMI 1640 medium, supplemented with $10 \%$ heat-inactivated FCS, $2 \mathrm{mM}$ L-glutamine, 100 $\mathrm{U} / \mathrm{mL}$ of penicillin $\mathrm{G}$ and $100 \mu \mathrm{g} / \mathrm{mL}$ of streptomycin). One hundred $\mu \mathrm{L}$ of spleen cells suspension $\left(2.5 \times 10^{5}\right.$ cells $/ 100 \mu \mathrm{L} /$ well $)$ were plated in 96-well U-bottom plates (Nunc, Roskilde, Denmark) and incubated at $37^{\circ} \mathrm{C}$ for $30 \mathrm{~min}$ in a fully humidified atmosphere containing $5 \% \mathrm{CO}_{2}$. Fifty $\mu \mathrm{L}$ of 2-mercaptoethanol (2-ME) $(0.2 \mathrm{mM})$, diluted with the basal culture medium, was added into each well.
The different doses of red and green Bell pepper extracts $(0.1876,0.375,0.75,1.5,2.25$ and 3.0 $\mathrm{mg} / \mathrm{mL}$ ) were prepared with the dilution of basal culture medium and $50 \mu \mathrm{L}$ of extract solution was added to each well in culture plates which were incubated for 5 or 7 days with or without the incorporation of extracts and standard immunostimulating agent, lipopolysaccharide (LPS: $0.01 \mu \mathrm{g} / \mathrm{mL}$ ). In control group, the splenocytes in each well were cultured with $50 \mu \mathrm{L}$ of 2mercaptoethanol and $50 \mu \mathrm{L}$ of basal culture medium only, without any treatment. The cultured supernatants were then collected and frozen at $-30^{\circ} \mathrm{C}$ for IgM-ELISA and the cells pellets were used for proliferation study.

Determination of the production of $\operatorname{IgM}$ and $\operatorname{IgG}$ antibodies by ELISA method: The levels of IgM and IgG antibodies were measured by a sandwich ELISA as described previously (Sarker et al., 2012b; Sarker et al., 2012c; Sarker et al., 2011; Sarker and Gohda, 2013). Briefly, each well of 96-well microtiter plates (Maxisorp, Nunc, Roskilde, Denmark) was coated with $50 \mu \mathrm{L} /$ well of goat anti-mouse IgM antibody (10 $\mu \mathrm{g} / \mathrm{mL}$ ), diluted with phosphate buffer saline (PBS), and incubated overnight in the dark at $4^{\circ} \mathrm{C}$. The plates were washed three times by PBS containing $0.05 \%$ Tween 20 (wash-buffer) $(200 \mu \mathrm{L} /$ well). The wells were blocked with $200 \mu \mathrm{L}$ of $1 \%$ bovine serum albumin (BSA) in PBS for 2 hours at room temperature. After washing the plates, $100 \mu \mathrm{L} /$ well of cultural supernatants (diluted with 1\% BSA-PBSTween 20, accordingly) or standard mouse-IgM were added into each well and the plates were incubated for 2 hours at room temperature. The plates were again washed three times by wash buffer (composition: $50 \mathrm{mM}$ Tris, $0.14 \mathrm{M} \mathrm{NaCl}, 0.05 \%$ Tween 20, pH 8.0) (200 $\mu \mathrm{L} /$ well). Fifty $\mu \mathrm{L}$ per well of horseradish peroxidase-conjugated goat antimouse IgM antibody $(0.2 \mu \mathrm{g} / \mathrm{mL})$ was added into each well and the plates were incubated for $1 \mathrm{~h}$ at room temperature. After washing the plates, 100 $\mu \mathrm{L} /$ well of $0.1 \mathrm{M}$ citrate buffer ( $\mathrm{pH} 4.0$ ) containing $2.5 \mathrm{mM}$ 2,2'-azino-bis (3-ethylbenzthiazoline-6sulfonic acid) and $0.17 \% \mathrm{H}_{2} \mathrm{O}_{2}$ were added. The plates were incubated for $10 \mathrm{~min}$ at room temperature 
and the optical densities at $405 \mathrm{~nm}$ were measured using an automatic plate reader (Bio-Rad Laboratories, USA).

Statistical analysis of data: The results are expressed as mean \pm S.E.M. of three or five independent experiments, or S.D. of triplicate cultures. The data were analyzed by one-way analysis of variance (ANOVA) followed by (Tukey's HSD test). $P$ values less than $5 \%$ were considered as significant.

\section{Results}

Enhancement of polyclonal IgM production in murine splenocytes by red Bell pepper extract, not by green Bell pepper extract: BALB/c female mice spleen B cells were cultured with or without different doses of red and green colored Bell pepper extracts for 5 days and the amount of IgM production in the cultural supernatants were determined by an IgMELISA. As shown in the Fig. 1, the red Bell pepper extract enhanced polyclonal IgM production in a bellshaped dose-response manner. The extract at the doses of $0.375 \mathrm{mg} / \mathrm{mL}, 0.75 \mathrm{mg} / \mathrm{mL}, 1.5 \mathrm{mg} / \mathrm{mL}$ and $2.25 \mathrm{mg} / \mathrm{mL}$ significantly increased $\mathrm{IgM}$ production in B cells compared to untreated cells. The highest enhancement was $300 \%$ at a dose of $1.5 \mathrm{mg} / \mathrm{mL}$ compared to control. On the contrary, none of the doses of green Bell pepper extract could increase in $\operatorname{IgM}$ production at all, in the supernatants of same culture.

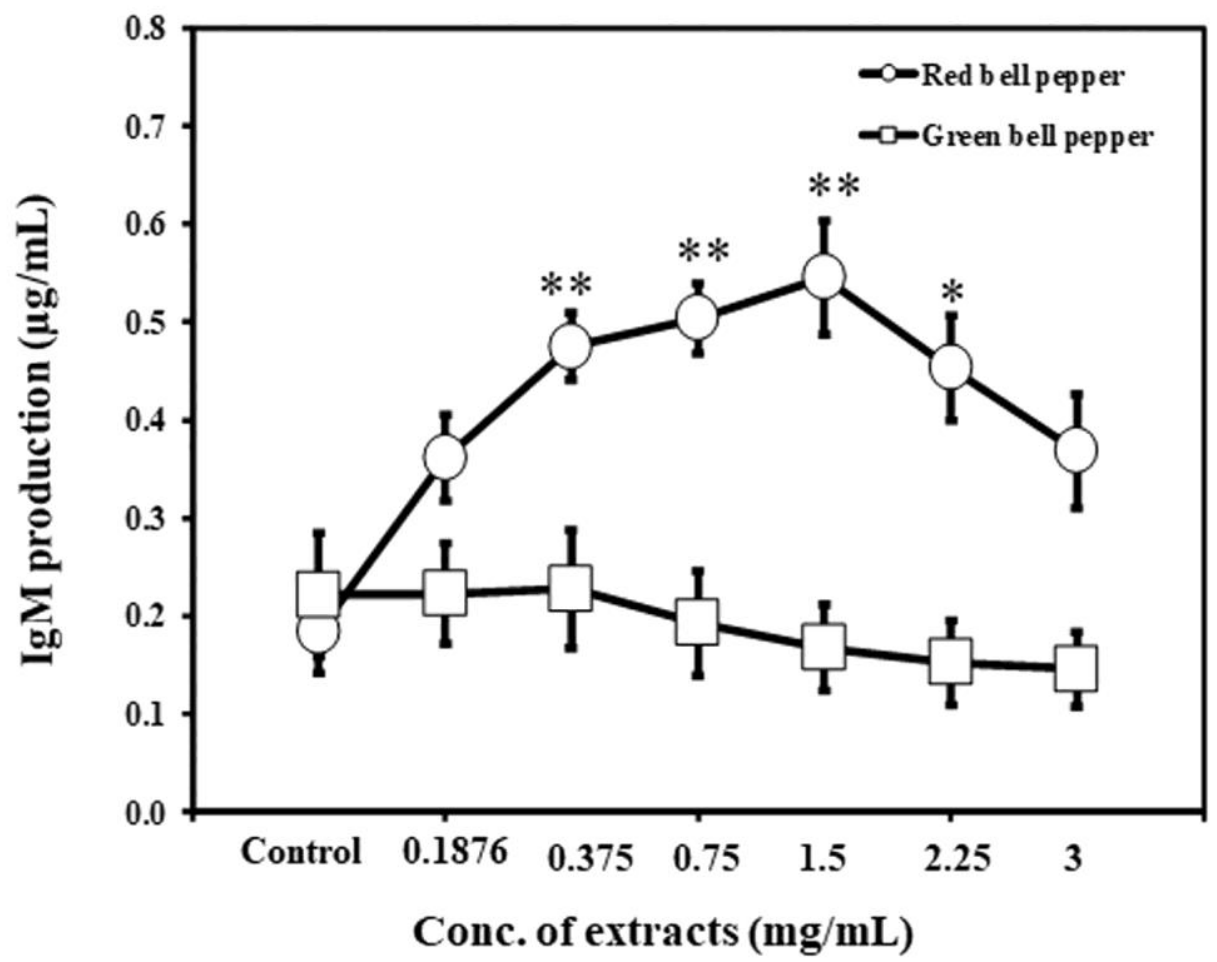

Figure 1. Evaluation of the activity of red and green colored Bell pepper extracts for the production of $\operatorname{IgM}$ antibody in cultural supernatants of murine whole spleen cells. BALB/c mice spleen cells $\left(2.5 \times 10^{5}\right.$ cells/well $)$ were incubated with the indicated concentrations of red and green Bell pepper extracts at $37^{\circ} \mathrm{C}$ in the $5 \% \mathrm{CO}_{2}$ incubator for 5 days. The IgM level in the supernatants was determined by an ELISA. The data are expressed as mean \pm S.E.M. of five (red Bell pepper extract) or three (green Bell pepper extract) independent experiments. $* P<0.05$ and $* * P<0.01$, as compared with the control (Tukey's HSD test).

Red Bell pepper extract (RBPE) significantly promoted IgG antibody production in murine B cells but green Bell pepper extract (GBPE) did not show any immune stimulating activity: BALB/c female mice whole spleen cells were incubated with or without different doses of the RBPE and GBPE for 7 
days and the amounts of IgG in the cultural supernatants were determined by ELISA. As shown in the Figure 2, the red Bell pepper extract significantly enhanced IgG production in a dose- response manner likewise as shown in Figure 1. On the other hand, none of the doses of GBPE could stimulate the production of IgG.

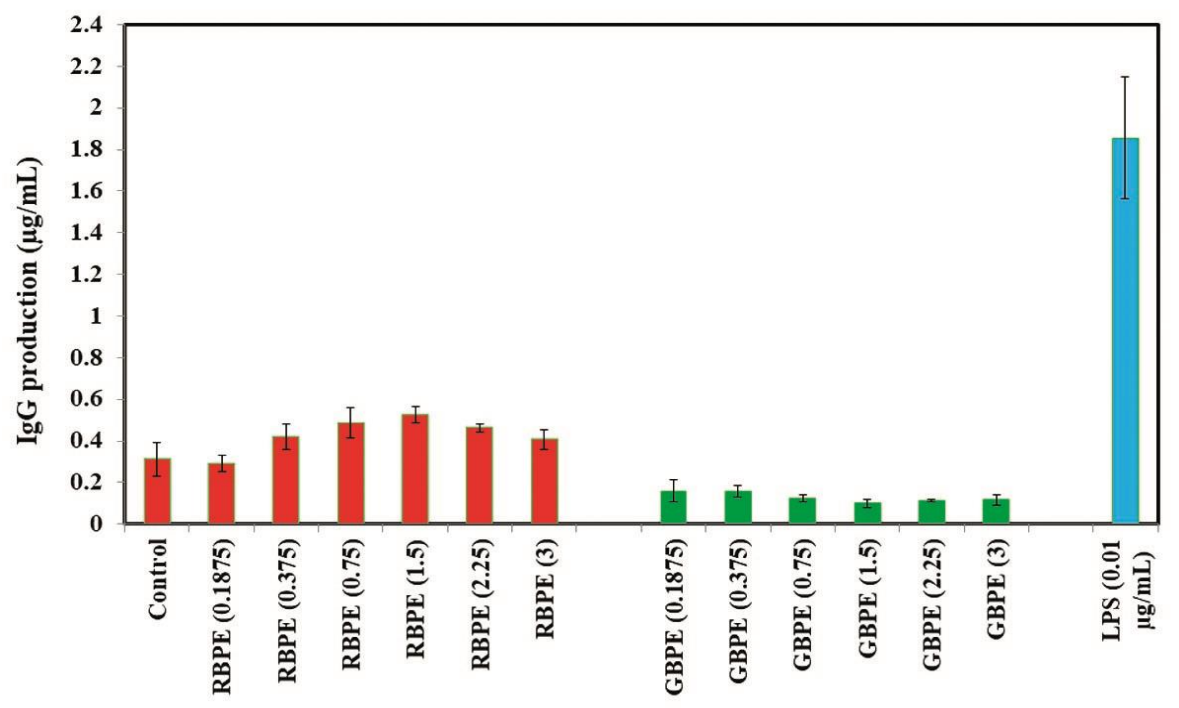

Concentrations of Bell pepper extracts $(\mathrm{mg} / \mathrm{mL})$

Figure 2. Evaluation of the activity of red and green colored Bell pepper extracts for the production of $\operatorname{IgG}$ antibody in cultural supernatants of murine whole splenocytes. BALB/c mice spleen cells $\left(2.5 \times 10^{5}\right.$ cells/well $)$ were incubated with the indicated concentrations of red and green Bell pepper extracts at $37^{\circ} \mathrm{C}$ in the $5 \% \mathrm{CO}_{2}$ incubator for 7 days. The $\mathrm{IgG}$ level in the supernatants was determined by an ELISA. The data are expressed as mean \pm S.D. of triplicate cultures.

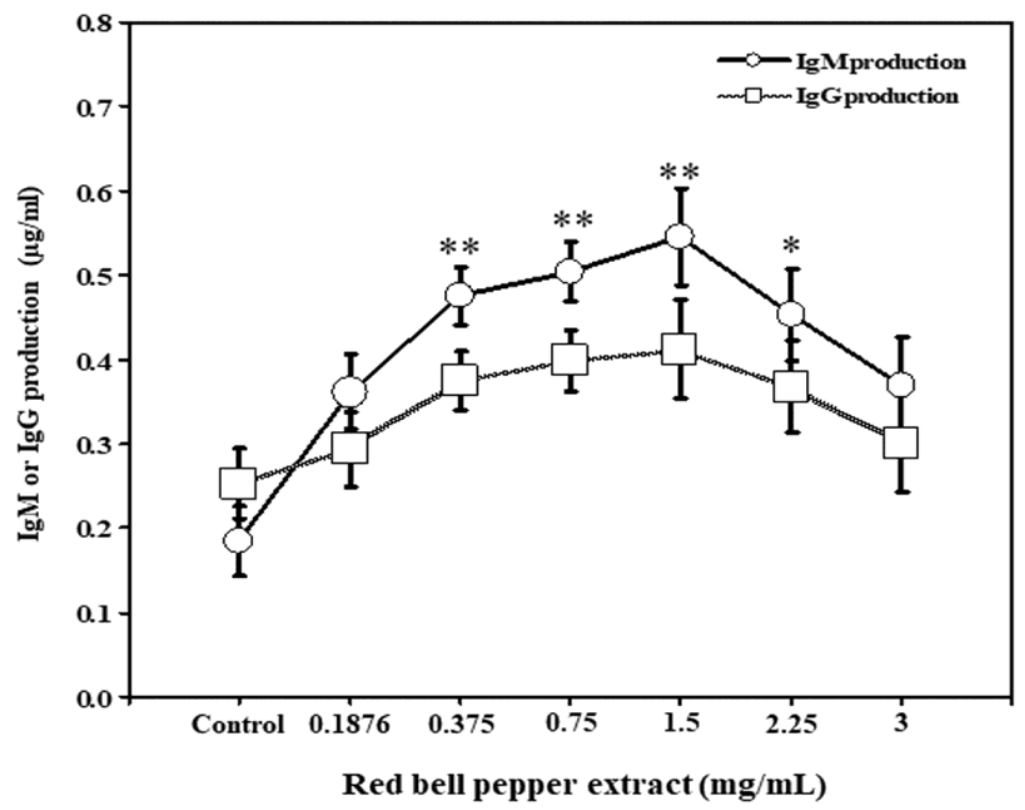

Fig 3. Comparison of the level of $\operatorname{IgM}$ and $\operatorname{IgG}$ production in culture supernatants of murine B cells by red Bell pepper extract in murine spleen cells in culture. BALB/c mice spleen cells $\left(2.5 \times 10^{5}\right.$ cells/well $)$ were cultured with the indicated concentrations of red Bell pepper extracts at $37^{\circ} \mathrm{C}$ and $5 \% \mathrm{CO}_{2}$ maintaining incubator for 5 and 7 days, respectively. The IgM and IgG production in cultural supernatants were determined by ELISA. Each point is the mean of \pm S.E.M. of five independent experiments (Tukey HSD). ${ }^{*} \mathrm{p}<0.05$ and ${ }^{*} \mathrm{p}<0.001$ as compared to control. 


\section{Discussion}

The findings of the present study demonstrated that between the red and green Bell peppers, only the red Bell pepper extract has exhibited its immunostimulating ability which was evident from its effect with the augmentation of the levels of both IgM and IgG antibodies (Figures 1 and 2). On the contrary, the green Bell pepper does not have immunostimulating ability to increase either IgM or IgG antibodies. This means the active ingredient(s) of Bell pepper extract responsible for the immunopotentiating activity is not common ingredient(s) of all colored Bell peppers. RBPE promoted the differentiation of $\mathrm{B}$ cells to plasma cells in polyclonal responses that is evident from the formation of enhanced IgM (Figure 1) and IgG (Fig. 2). Our research group previously reported the promotion of the differentiation and the proliferation of murine B cells by RBPE in antigen-specific antibody productions in immune responses (Sarker and Gohda, 2013). However, the IgM antibody production ability of red Bell pepper extract was found to be higher than that of $\mathrm{IgG}$ antibodies produced by the same doses of red Bell pepper extract (Fig. 3).

Antibodies have the ability to neutralize toxins, protect the invasion of microorganisms into host cells, make microbes susceptible to phagocytosis by giving a coat on it, and activate complement cascade by forming antibody(Ab)-antigen complexes (Ollila and Vihinen, 2005). IgM Ab is produced in primary immune response and act as vanguard for antigen defense in an early phase of antigen removal. IgG Abs are generated following class switching and maturation of the $\mathrm{Ab}$ response; thus predominant in secondary immune response (Roitt et al., 2001). IgM and $\mathrm{IgG}$ Abs together provide total humoral immunity (short-term and long-term protection) of the body to fight against all sorts of foreign pathogens, cancer cells and toxic substances (Sebina and Pepper, 2018). That's why, we evaluated the activity of RBPE and GBPE for the induction of IgM and $\mathrm{IgG} \mathrm{Ab}$ productions.
The selection of an ideal dose is the key to achieve the desired immunostimulation. When the dose of an immunostimulant surpasses optimal level, it exhibits suppressive activity in general (Calabrese and Baldvin, 2001). As shown in the Figs. 1 and 2, the optimum dose of RBPE for both IgM and IgG productions was $1.5 \mathrm{mg} / \mathrm{mL}$. The activity of RBPE was suppressed with the increasing of doses beyond the optimal dose. The extract doses 2.25 and 3.0 $\mathrm{mg} / \mathrm{mL}$ exhibited declined activity after its optimum dose $1.5 \mathrm{mg} / \mathrm{mL}$. Calabrese et al. reported that immunostimulants usually display suppressive activity, if the dose surpasses optimal level (Calabrese and Baldvin, 2001). The main reason of immunosuppression by red Bell pepper extract at higher doses is not known. However, the extract may contain some chemical(s) that are active at higher concentration(s).

Immunostimulants are crucially important for the prevention and treatment of cancer (the appearance of cancer is a failure of immune surveillance to destroy cancer cells as soon as they appear); mitigation of immunodeficiency diseases; to retain normal immunity in general immunosuppression following drug treatment or during chemotherapy for the treatment of cancer; for combination therapy with antibiotics to reduce the use of antibiotic or to enhance the pharmacological response of the antibiotic/antimicrobial drugs against the infected microbes (robust immune response in coordination with drug to clear infection); and as immunogenic adjuvants for vaccines (Popov et al., 2010). Bacterial poly-resistance to antibiotics and its side-effects including allergy, immunosuppression, etc. greatly demands the introduction of new and effective immunostimulants (Petrunov et al., 2007). Currently using synthetic adjuvants and immunostimulants, such as levamisole, thalidomide, etc., are toxic towards normal cells and exhibit many serious sideeffects including hepatotoxicity, nephrotoxicity, hypertension, bone marrow depression, myalgia, etc. (Diasio and LoBuglio, 1996). Therefore, it is very necessary to search for novel immunostimulant(s) having no or minimum side-effect(s) and are potent 
enough to induce humoral and cellular immunity for the entire defense of the body. Plants, fruits, vegetables and spices are among the most important targets to search for such immunomodulators as these materials are safer, cheaper and effective without side-effects. Recently, there is a growing interest to know the therapeutic and nutritional value of the dietary materials and to use dietary supplements to boost immune responses (Carrasco et al., 2009). Dietary materials, with their bioactive substances, directly influence the functional activities of our body for energy, growth, nutrition and defence, and many other therapeutic activities including diabetes, cancer, immunity, inflammation, infections, hyperlipidemia, etc. (Kifayatullah et al., 2017; Sarker et al., 2016; Sarker et al., 2015; Shah et al., 2016; Shajib et al., 2018; Sheikh et al., 2017a; Sheikh et al., 2017b). Red Bell pepper fruit is eaten all over the world as vegetables. Hence, the red Bell pepper or its extract can be a strong candidate that may be used for the stimulation of antigen-specific humoral immune responses.

\section{Conclusion}

Our data clearly demonstrates that RBPE promoted the production of both $\operatorname{IgM}$ and $\operatorname{IgG}$ antibodies in polyclonal responses, whereas GBPE could not promote the production of neither IgM nor IgG antibodies. Although green Bell pepper may be enriched with several other phytoconstituents that may be beneficial for other healthcare purposes, none of the phytoconstituents present in the aqueous extract of our investigation could exhibit the immunoenhancement in the culture of murine whole spleen cells. To the best of our knowledge, this is the first report on the activity of GBPE on immunity for antibody production. Based on experiment results we can conclude that red Bell pepper fruit (as food material) or its extract, in combination with other chemicals, may be beneficial to induce immune responses in case of suppressed immune functions or to enhance the normal immunological status to protect against infections or as an immune adjuvant in vaccine. Further investigations and identification of the active ingredient(s) from RBPE may lead to the invention of novel immunostimulants that may be used for the maintenance or strengthening of immunity.

List of Abbreviations: Ab: Antibody, ANOVA: Analysis of variance, BSA: Bovine serum albumin, ELISA: Enzyme-linked immunosorbent assay, FCS: Fetal calf serum, HRP: Horseradish peroxidase, Ig: Immunoglobulin, LPS: Lipopolysaccharide, ME: Mercaptoethanol, MTT: 3-(4,5-dimethylthiazol-2-yl)2,5-diphenylterazolium bromide, PBS: Phosphate buffered saline, RBPE: Red Bell pepper extract, GBPE: Green Bell pepper extract, RPMI: Roswell Park Momorial Institute.

\section{Conflict of interest}

Not applicable.

\section{Acknowledgement}

The author is grateful to the Department of Immunochemistry, Faculty of Pharmaceutical Sciences, Okayama University, Japan, to carry out experiments of this study.

\section{References}

Ankomah, P. and Levin, B.R. 2014. Exploring the collaboration between antibiotics and the immune response in the treatment of acute, self-limiting infections. Proc. Natl. Acad. Sci. 111, 8331-8338.

Besedovsky, L., Lange, T. and Haack, M. 2019. The SleepImmune Crosstalk in Health and Disease. Physiol Rev. 99, 1325-1380.

Calabrese, E. J., and Baldvin, L. A. 2001. Hormesis: ushaped dose-responses and their centrality in toxicology. Trends Pharmacol. Sci. 22, 285-288.

Carrasco, F. R., Schmidt, G., Romero, A. L., Sartoretto, J. L., Caparroz-Assef, S. M., Bersani-Amado, C. A., and Cuman, R. K. 2009. Immunomodulatory activity of Zingiber officinale Roscoe, Salvia officinalis L. and Syzygium aromaticum L. essential oils: evidence for tumor- and cell-mediated responses. J. Pharm. Pharmacol. 61, 961-967.

Chen, Y., Liu, D., Wang, D., Lai, S., Zhong, R., Liu, Y., Yang, C., Liu, B., Sarker, M.M.R. and Zhao, C. 2019. Hypoglycemic activity and gut microbiota regulation of a novel polysaccharide from Grifola frondosa in type 2 diabetic mice. Food Chem. Toxicol. 126, 295302. 
Chen, Y., Liu, D., Wang, D., Lai, S., Zhong, R., Liu, Y., Yang, C., Liu, B., Sarker, M.M.R. and Zhao, C. 2019. Hypoglycemic activity and gut microbiota regulation of a novel polysaccharide from Grifola frondosa in type 2 diabetic mice. Food Chem. Toxic. 126, 295302.

Chen, Y., Liu, Y., Sarker, M.M.R., Yan, X., Yang, C., Zhao, L., Lv, X., Liu, B. and Zhao, C. 2018. Structural characterization and antidiabetic potential of a novel heteropolysaccharide from Grifola frondosa via IRS1/PI3K-JNK signaling pathways. Carbohydrate polymers, 198, 452-461.

Das, S.K., Sengupta, P., Mustapha, M.S. and Sarker, M.M.R. 2017. An experimental evaluation of adaptogenic potential of standardized epipremnum aureum leaf extract. J Pharm. Bioallied Sci. 9, 88-93.

Diasio, R. B. and LoBuglio, A. F. 1996. Immunomodulators: immunosuppressive agents and immunostimulants. In: J. G. Hardman, \& L. E. Limbird (Eds.), Goodman and Gilman's: The pharmacological basis of therapeutics (pp.12911307). New York: McGraw-Hill.

Ghasemnezhad, M., Sherafati, M. and Payvast, G. A. 2011. Variation in phenolic compounds, ascorbic acid and antioxidant activity of five coloured Bell pepper (Capsicum annum) fruits at two different harvest times. J. Funct. Foods 3, 44-49.

Goswami, M., Prince, G., Biancotto, A., Moir, S., Kardava, L., Santich, B.H., Cheung, F., Kotliarov, Y., Chen, J., Shi, R. and Zhou, H., 2017. Impaired B cell immunity in acute myeloid leukemia patients after chemotherapy. J. Trans. Med. 15, 1-16.

Goto, T., Sarker, M. M. R., Zhong, M., Tanaka, S. and Gohda, E. 2010. Enhancement of immunoglobulin M production in B cells by the extract of red Bell pepper. J. Health Sci. 56, 304-309.

Günther, J. and Seyfert, H.M. 2018. The first line of defence: insights into mechanisms and relevance of phagocytosis in epithelial cells. Semin. Immunopathol. 40, 555-565.

Hickman, D., Jones, M.K., Zhu, S., Kirkpatrick, E., Ostrov, D.A., Wang, X., Ukhanova, M., Sun, Y., Mai, V., Salemi, M. and Karst, S.M. 2014. The effect of malnutrition on norovirus infection. MBio, 5, e0103213.

Kamarudin, M.N.A., Sarker, M.M.R., Kadir, H.A. and Ming, L.C. 2017. Ethnopharmacological uses, phytochemistry, biological activities, and therapeutic applications of Clinacanthus nutans (Burm. f.) Lindau: A comprehensive review. J. Ethnopharmacol. 206, 245-266.
Karim, M.F.B., Imam, H., Sarker, M.M.R., Uddin, N., Hasan, N., Paul, N. and Haque, T. 2015. Free radical scavenging, antidiarrheal and anthelmintic activity of Pistia stratiotesL. extracts and its phytochemical analysis. Pak. J. Pharm. Sci. 28, 915-920.

Sarker, P., Rahman, M.M., Khan, F., Ming, L.C., Mohamed, I.N., Zhao, C. and Rashid, M.A. 2019. Comprehensive Review on Phytochemicals, Pharmacological and Clinical Potentials of Gymnema sylvestre. Front. Pharmacol. 10, 1223.

Kidd, B.A., Wroblewska, A., Boland, M.R., Agudo, J., Merad, M., Tatonetti, N.P., Brown, B.D. and Dudley, J.T. 2016. Mapping the effects of drugs on the immune system. Nat. Biotechnol. 34, 47-54.

Kifayatullah, M., Mustapha, M.S., Sarker, M.M.R. and Amin, M. 2017. Effect of compounds identified in the active fraction of Pericampylus glaucus on blood glucose and lipid profiles in streptozotocin-induced diabetic rats. Egypt. Pharmaceut. J. 16, 8-15.

Munira, S., Nesa, L., Islam, M.S., Begum, Y., Rashid, M.A., Sarker, M.R. and Ahmed, T. 2020. Antidiabetic activity of Neolamarckia cadamba (Roxb.) Bosser flower extract in alloxan-induced diabetic rats. Clin. Phytosci. 6, 33.

Nesa, M.L., Karim, S.S., Api, K., Sarker, M.M.R., Islam, M.M., Kabir, A., Sarker, M.K., Nahar, K., Asadujjaman, M. and Munir, M.S. 2018. Screening of Baccaurea ramiflora (Lour.) extracts for cytotoxic, analgesic, anti-inflammatory, neuropharmacological and antidiarrheal activities. BMC Complement. Altern. Med. 18, 35.

Ollila, J. and Vihinen, M. 2005. B cells. Int. J. Biochem. Cell Biol. 37, 518-523.

Paiardini, M., Frank, I., Pandrea, I., Apetrei, C. and Silvestri, G. 2008. Mucosal immune dysfunction in AIDS pathogenesis. AIDS Rev. 10, 36-46.

Park, J.H., Jeon, G.I., Kim, J.M. and Park, E. 2012. Antioxidant activity and antiproliferative action of methanol extracts of 4 different colored Bell peppers (Capsicum annuum L.). Food Sci. Biotechnol. 21, 543550.

Petrunov, B., Nenkov, P. and Shekerdjiisky, R. 2007. The role of immunostimulants in immunotherapy and immunoprophylaxis. Biotechnol. Biotechnol. Equip. 21, 454-462.

Popov, B., Dobreva, Z. 1., Georgieva, Sv. and Stanilova, S. 2010. Enhancement of anti-KLH IgG antibody production in rabbits after treatment with Harberlea rhodopensis extract. Trakia J. Sci. 8, 92-97.

Ren, C., Yao, R.Q., Zhang, H., Feng, Y.W. and Yao, Y.M., 2020. Sepsis-associated encephalopathy: a vicious cycle of immunosuppression. J. Neuroinflammation. 17, 14. 
Roitt, I., Brostoff, J., and Male, D. (Eds.) 2001. Immunology $\left(6^{\text {th }}\right.$ ed.). Kidlington, United Kingdom: Elsevier Health Sciences.

Sancho, R., Lucera, C., Macho, A., Calzado, M. A., Blanco-Molina, M., Minassi, A., Appendino, G. and Munnoz, E. 2002. Immunosuppressive activity of capsaicinoids: capsiate derived from sweet peppers inhibits NF- $\kappa \mathrm{B}$ activation and is a potent antiinflammatory compound in vivo. Eur. J. Immunol. 32, 1753-1763.

Sarker, M.M.R. and Gohda, E. 2013. Promotion of antikeyhole limpet hemocyanin $\operatorname{IgM}$ and $\operatorname{IgG}$ antibody productions in vitro by red Bell pepper extract. $J$. Funct. Foods. 5, 1918-1926.

Sarker, M.M.R., Zihad, M.A.T.R., Islam, M., Nahar, M., Islam, M.M., Imam, H., Ghosh, A., Mustapha, M.S. and Ismail, N.E. 2015. Antihyperglycemic, insulinsensitivity and anti-hyperlipidemic potential of Ganoderma lucidum, a dietary mushroom, on alloxanand glucocorticoid-induced diabetic Long-Evans rats. Funct. Foods Health Dis. 5, 450-466.

Sarker, M.M.R., Choudhuri, M.S.K. and Zhong, M. 2012c. Effect of Chandanasav, an Ayurvedic formulation, on mice whole splenocytes for the production of polyclonal IgM and proliferation of cells-A preliminary study. Int. J. Pharm. Sci. Res. 3, 12941299.

Sarker, M.M.R., Imam, H., Ahmed, S. and Choudhuri, M.S.K. 2014. In vitro assessment of Prasarani Sandhan, a traditional polyherbal Ayurvedic medicine, for immunostimulating activity splenic cells of BALB/c mice. Int. J. Pharm. Pharm. Sci. 6, 13-15.

Sarker, M.M.R., Mazumder, M.E.H. and Rashid, M.H. 2011. In vitro Enhancement of Polyclonal IgM Production by Ethanolic Extract of Nigella sativa L. seeds in whole Spleen Cells of Female BALB/c Mice. Bangladesh Pharm. J. 14, 73-77.

Sarker, M.M.R., Ming, L.C., Sarker, M.Z.I. and Choudhuri, M.S.K., 2016. Immunopotentiality of Ayurvedic polyherbal formulations "Saribadi" and "Anantamul Salsa" with augmentation of IgM production and lymphocytes proliferation: a preliminary study. Asian Pac. J. Trop. Biomed. 6, 568-573.

Sarker, M.M.R., Nimmi, I. and Kawsar, M. H. 2012 b. Preliminary screening of six popular fruits of Bangladesh for in vitro $\operatorname{IgM}$ production and proliferation of splenocytes. Bangladesh Pharm. J. 15, 31-37.
Sarker, M.M.R., Nahar, S., Shahriar, M., Seraj, S. and Choudhuri, M.S.K., 2012. Preliminary study of the immunostimulating activity of an ayurvedic preparation, Kanakasava, on the splenic cells of BALB/c mice in vitro. Pharm. Biol. 50, 1467-1472.

Sarker, M.M.R. 2012. Induction of humoral immunity through the enhancement of $\operatorname{IgM}$ production in murine splenic cells by ethanolic extract of seed of Piper nigrum L. J. Sci. Res. 4, 65-69.

Sebina, I., Pepper, M. 2018. Humoral immune responses to infection: common mechanisms and unique strategies to combat pathogen immune evasion tactics. Current opinion in immunology, 51, 46-54.

Shah, M.A., Sarker, M.M.R. and Gousuddin, M. 2016. Antidiabetic potential of Brassica oleracea var. Italica in type 2 diabetic sprague dawley (SD) rats. Int. J. Pharmacog. Phytochem. Res. 8, 462-469.

Shajib, M., Rashid, R.B., Ming, L.C., Islam, S., Sarker, M.M.R., Nahar, L., Sarker, S.D., Datta, B.K. and Rashid, M.A. 2018. Polymethoxyflavones from Nicotiana plumbaginifolia (Solanaceae) exert antinociceptive and neuropharmacological effects in mice. Front. Pharmacol. 9, 85.

Sheikh, B.Y., Sarker, M.M.R., Kamarudin, M.N.A. and Mohan, G. 2017. Antiproliferative and apoptosis inducing effects of citral via p53 and ROS-induced mitochondrial-mediated apoptosis in human colorectal HCT116 and HT29 cell lines. Biomed. Pharmacother. 96, 834-846.

Sheikh, B.Y., Sarker, M.M.R. Kamarudin, M.N.A. and Ismail, A. 2017. Prophetic Medicine as potential functional food elements in the intervention of cancer: A review. Biomed. Pharmacother. 95, 614-648.

Toniolo, A., Cassani, G., Puggioni, A., Rossi, A., Colombo, A., Onodera, T. and Ferrannini, E. 2019. The diabetes pandemic and associated infections: suggestions for clinical microbiology. Rev. Med. Microbiol. 30, 117.

Vitlic, A., Lord, J.M. and Phillips, A.C. 2014. Stress, ageing and their influence on functional, cellular and molecular aspects of the immune system. Age (Dordr). 36, 9631.

Zlotnikov, N., Javid, A., Ahmed, M., Eshghi, A., Tang, T.T., Arya, A., Bansal, A., Matar, F., Parikh, M., Ebady, R. and Koh, A. 2017. Infection with the Lyme disease pathogen suppresses innate immunity in mice with diet-induced obesity. Cell Microbiol. 19, e12689. 